\begin{tabular}{|c|c|c|}
\hline $\mathrm{S}$ & & \\
\hline
\end{tabular}

DOI: https://doi.org/10.31743/spw.13089

PAWEŁ KAŹMIERSKI*

\title{
XVIII OGÓLNOPOLSKIE SYMPOZJUM \\ PRAWA WYZNANIOWEGO \\ PT. WOLNOŚĆ UZEWNĘTRZNIANIA PRZEKONAŃ RELIGIJNYCH, MAŁA WIEŚ, 7-9 WRZEŚNIA 2021 R.
}

XVIII National Symposium on Law on Religion Freedom to manifest religious beliefs, Mała Wieś, 7-9 September 2021

W dniach 7-9 września 2021 r. w Pałacu Lubomirskich w Małej Wsi koło Grójca odbyło się XVIII Ogólnopolskie Sympozjum Prawa Wyznaniowego poświęcone tematyce wolności uzewnętrzniania przekonań religijnych. Jego organizatorem były: Wydział Prawa i Administracji i Wydział Prawa Kanonicznego Uniwersytetu Kardynała Stefana Wyszyńskiego oraz Polskie Towarzystwo Prawa Wyznaniowego. Z powodu utrzymującej się sytuacji pandemicznej udział w sympozjum możliwy był osobiście lub w formie zdalnej.

Uroczystego otwarcia sympozjum dokonał Prezes Polskiego Towarzystwa Prawa Wyznaniowego, dr hab. Marek Bielecki, prof. ASzWoj. Plenarnej sesji sympozjum przewodniczył dr hab. Tadeusz Stanisławski, prof. UZ. W ramach tej sesji referaty wygłosili: ks. dr hab. Piotr Steczkowski, prof. URz, pt. Wolność religijna w doktrynie i praktyce Stolicy Apostolskiej za pontyfikatu papieża Franiczka; dr hab. Paweł Sobczyk, prof. UO, pt. Pojęcie ,, uzewnętrznianie” w odniesieniu do wolności (religijnej); prof. dr hab. Tadeusz J. Zieliński (ChAT), pt. Gwarancje prawnooświatowe dla mniejszości wyznaniowych i światopoglądowych (przegląd zagadnień); dr hab. Paweł Borecki (UW), pt. Wolność uzewnętrzniania przekonań

\footnotetext{
Mgr, Pracownia Prawa Kościelnego i Wyznaniowego, Wydział Prawa i Administracji, Uniwersytet Jagielloński, ul. Gołębia 9, 31-007 Kraków, e-mail: pawel.kazmierski@ doctoral.uj.edu.pl. ORCID 0000-0001-8287-3419.
} 
religijnych przez osoby sprawujace władze publiczna w świetle prawa polskiego oraz ks. dr hab. Piotr Stanisz, prof. KUL, pt. Ograniczenia wolności kultu religijnego ze względu na ochrone zdrowia publicznego, uwagi na temat nieprzygotowania polskiego prawa na czas epidemii. Po wygłoszeniu referatów nastąpiła dyskusja, po której udano się na kolację, wieńczącą pierwszy dzień sympozjum.

Drugiego dnia obrady były prowadzone w ramach trzech równolegle odbywających się sesji. Sesje A i B odbywały się stacjonarnie w Małej Wsi. Sesja C została przeprowadzona w formie zdalnej.

Sesji A przewodniczył dr hab. Paweł Sobczyk, prof. UO. Referaty w części porannej wygłosili: dr hab. Andrzej Szymański, prof. UO, pt. Sprawa księdza Norka. Próba zadeklarowania przekonań religijnych (i politycznych) $w$ dobie stalinizmu; dr hab. Marek Bielecki, prof. ASzWoj, pt. Możliwość uzewnętrzniania przekonań religijnych $w$ polskiej szkole; $\mathrm{dr}$ hab. Jerzy Nikołajew, prof. UO, pt. Korzystanie z wolności religijnej a zakłócanie ustalonego porządku w zakładzie karnym; dr hab. Tadeusz Stanisławski, prof. UZ, pt. Identyfikacja wyznaniowa $w$ dokumentach podatkowych $i$ ubezpieczeniowych oraz dr hab. Anna Tunia, prof. KUL, pt. Prawo wykroczeń jako instrument skutecznej wolności uzewnętrzniania przekonań religijnych. Następnie przeprowadzono dyskusję, po której nastąpiła przerwa kawowa.

W trakcie Sesji B moderowanej przez dr. hab. Konrada Walczuka, prof. ASzWoj, referaty w części porannej wygłosili: ks. dr hab. Mieczysław Różański, prof. UWM, pt. Ograniczenia praktyk religijnych w Kościele Rzymskokatolickim w Polsce w czasie pandemii COVID-19; dr Justyna Krzywkowska (UWM), pt. Opieka duchowa nad chorymi na COVID-19; dr Marek Paszkowski (UWM), pt. Prawo osadzonych do praktyk religijnych w czasie pandemii COVID-19 oraz dr Michał Poniatowski (UKSW), pt. Projekt ustawy o sprawozdawczości organizacji pozarzadowych a wolność uzewnętrzniania przekonań religijnych. Po dyskusji udano się na krótką przerwę.

Jednocześnie z dwoma stacjonarnymi sesjami rozpoczęła się Sesja C w formie online, moderowana przez dr hab. Martę Osuchowską (UKSW). Referaty w pierwszej części wygłosili: prof. dr hab. Józef Koredczuk (UWr), pt. Uzewnętrznianie przekonań religijnych przez wyznania prawnie nieuznane; prof. dr hab. Zbigniew Pasek (AGH), pt. Czy miesięcznice 
smoleńskie były uroczystościami religijnymi? Głos $w$ sprawie relacji między prawem a kultura religijna; dr hab. Wojciech Brzozowski, prof. UW, pt. Prozelityzm niewłaściwy oraz dr hab. Grzegorz Maron (URz), pt. Ekspresja religijna na sali sądowej - wybrane zagadnienia w ujęciu prawnoporównawczym. Po dyskusji nastąpiła krótka przerwa przed dalszymi obradami.

Po krótkiej przerwie drugiej części obrad Sesji A przewodniczył dr hab. Paweł Sobczyk, prof. UO. Referaty wygłosili: prof. dr hab. Bartosz Rakoczy (UMK), pt. Problematyka stroju zakonnego w prawie kanonicznym i prawie polskim; ks. dr hab. Piotr Ryguła, prof. UKSW, pt. Gwarancje dotyczace zawarcia matżeństwa według norm prawa kanonicznego w prawie hiszpańskim; dr hab. Konrad Walczuk, prof. ASzWoj, pt. Gwarancje swobody działalności formacyjnej kościołów $i$ wspólnot religijnych w prawie słowackim; dr hab. Marta Osuchowska (UKSW), pt. Ograniczanie wolności religijnej $w$ przestrzeni publicznej $w$ państwach latynoamerykańskich oraz dr. Michaela Moravčiková (Uniwersytet w Trnawie, Słowacja), pt. Między wolnościa wypowiedzi a wolnościa religii. Po krótkiej dyskusji zakończono Sesję A i rozpoczęła się przerwa obiadowa.

Równolegle po przerwie kawowej odbywała się druga część Sesji B, którą moderował dr hab. Mieczysław Różański, prof. UWM. Referaty wygłosili: dr Marcin Olszówka (UŁaz), pt. Art. 25 ust. 2 Konstytucji jako dodatkowa gwarancja wolności uzewnętrzniania przekonań religijnych; dr Marek Strzała (UJ), pt. Terminologia przepisów zakazujących kultu religijnego $w$ zwiazku $z$ wystapieniem stanu epidemii wywołanym zakażeniem wirusem SARS COV-2 oraz mgr Jacek Kołota (UKSW), pt. Wolność uzewnętrzniania przekonań religijnych przez studentów podczas odbywania wojskowego szkolenia $w$ ramach programu Legii Akademickiej. Następnie miała miejsce intensywna dyskusja, po której zakończono Sesję B oraz udano się na przerwę obiadową.

W trakcie obrad sesji stacjonarnych kontynuowano również drugą część Sesji C (w formie online) moderowanej przez dr. hab. Marka Bieleckiego, prof. ASzWoj. Referaty wygłosili: dr hab. Rafał Łatka (BBH IPN), pt. Zepchnięcie Kościoła katolickiego do roli kruchty jako cel polityki wyznaniowej władz PRL - próba całościowego spojrzenia; dr Piotr Michalik (UJ), pt. Zgoda na zawarcie matżeństwa przez żydów w Wolnym Mieście Krakowie (1815-1846); mgr Edyta Włodarczyk-Czech (UWr), 
pt. Działalność Salwatorianów w Bagnie w latach 60. i 70. XX w. w kontekście wolności uzewnętrzniania przekonań religijnych $w$ Polsce Ludowej; dr Aneta Maria Abramowicz (KUL), pt. Ograniczenia wolności uzewnętrzniania religii $w$ warunkach więziennych $w$ świetle wyroku ETPCz z 12 maja 2020 r. w sprawie Korostelev przeciwko Rosji; dr Michał Zawiślak (KUL), pt. Prawo do zbiorowego uczestnictwa w ceremoniach religijnych. Postanowienie Conseil d'État z dnia 29.11.2020 roku oraz mgr Paulina Łabieniec (UŁ), pt. Argumentacja religijna nad prawem. Po dyskusji nastąpiła przerwa przed ostatnią częścią tej sesji.

Po przerwie obiadowej zostały wznowione obrady Sesji C (online). Uczestnicy sympozjum przybyli do Małej Wsi brali w niej udział indywidualnie lub wspólnie z moderującą, dr hab. Martą Osuchowską (UKSW). Referaty wygłosili: ks. dr Maciej Tomasz Kubala (US), pt. Ograniczenia wolności uzewnętrzniania przekonań religijnych we włoskim porzadku prawnym motywowane pandemia COVID-19; dr Konrad Zamirski (ChAT), pt. Równość religijna we współczesnej Ukrainie; dr Michał Ożóg (UwB), pt. Ochrona wolności uzewnętrzniania przekonań religijnych $w$ stanie epidemii w świetle Konstytucji Rzeczypospolitej Polskiej z dnia 2 kwietnia 1997 r.; dr Mariusz Grabowski (UKSW), pt. Wolność uzewnętrzniania przekonań religijnych $w$ świetle regulacji prawnych dotyczacych radiofonii $i$ telewizji; mgr Maksymilian Hau (UW), pt. Uzewnętrznianie przekonań religijnych przez partie polityczne; mgr Bartłomiej Oręziak (UKSW), pt. Problem uzewnętrznienia swoich przekonań $w$ Internecie waspekcie nowych zasad unijnego prawa autorskiego oraz dr hab. Jan Krajczyński, prof. UKSW, pt. Konflikt między prawem wewnętrznym związku wyznaniowego a prawem państwowym $w$ zakresie uzewnętrzniania przekonań religijnych. $\mathrm{Z}$ powodu znacznej liczby referentów i zaplanowanych w harmonogramie obrad organów Polskiego Towarzystwa Prawa Wyznaniowego nie starczyło czasu na końcową dyskusję.

Niedługo po zakończeniu Sesji C rozpoczęło się posiedzenie Zarządu, a następnie przystąpiono do obrad Walnego Zgromadzenia Członków Polskiego Towarzystwa Prawa Wyznaniowego, które przeprowadzono $\mathrm{w}$ formie stacjonarnej wraz z jednoczesnym udziałem oraz możliwością oddawania głosów przez pozostałych uczestników w formie zdalnej. Przedstawiono sprawozdanie z bieżącej działalności, a także sprawozdanie finansowe. Po zakończeniu obrad organów Towarzystwa istniała możliwość 
zwiedzania okolicy, a następnie miała miejsce uroczysta kolacja i zamknięcie sympozjum. Z pewnością publikacja pokonferencyjna umożliwi ponowną refleksję nad różnorodnymi problemami prawa wyznaniowego, które zostały poruszone $\mathrm{w}$ trakcie niezwykle interesujących wystąpień uczestników tegorocznego sympozjum. 
